DOI: 10.17707/AgricultForest.64.1.03

Fatma ACHEUK, Wassima LAKHDARI, Abderramene DAHLIZ,
Khemais ABDELLAOUI, Manel MOUKADEM, Souhila ALLILI

\title{
TOXICITY, ACETHYLCOLINESTERASE AND GLUTATHIONE S- TRANSFERASE EFFECTS OF HALOCNEMUM STROBILACEUM CRUDE EXTRACT AGAINST TRIBOLIUM CASTANEUM
}

\begin{abstract}
SUMMARY
Halocnemum stobilaceum (Chenopodiaceae) is one of many halophyte plants from Algerian Sahara. In this study, we investigate the phytochemical composition and the insecticidal activity of the crude ethanolic extract of this plant against adults of the red flour beetle Tribolium castaneum (Coleoptera: Tenebrionidae). Te effect of this extract on the detoxification enzyme Glutathione S-transferase (GST) and the neuroenzyme Acethylcolinesterase (AChE) was also investigated. The repellent effect was evaluated, at the concentration of $1000 \mu \mathrm{g} /$ insect, using the preferential zone method on blotting paper. The insecticidal effect was investigated by testing 5 doses: 100, 200, 400, 800 and $1000 \mu \mathrm{g} /$ insect.

The obtained results show that $H$. stobilaceum is very rich in saponins, gallic tannins, flavonoids, antocyans, coumarins and alkaloids. The plant is poor in irridoids. On insecticidal level, the extract tested at dose $1000 \mu \mathrm{g} /$ insecte has a good repellent effect on adults of $T$. castaneum. The repulsively rate calculated after two hours of exposure was $60 \%$. The extract was toxic too. Indeed, the five tested doses caused mortalities of 15, 33.3, 41.6, 48.3 and 70\%, respectively, after 6 hours of exposure. The highest dose $(1000 \mu \mathrm{g} / \mathrm{insect})$ generated 100 deaths after $96 \mathrm{~h}$ of exposure. The $\mathrm{LD}_{50}$ calculated $24 \mathrm{~h}$ after treatment was 225.4 $\mu \mathrm{g} /$ insect. Furthermore, the extract of this plant, at the concentration of 1000 $\mu \mathrm{g} /$ insect, inhibited acetylcholinesterase (AChE) activity. The obtained results suggest that extracts of this plant can be used to protect the stored products against insect secondary pest.
\end{abstract}

Keywords: Crude ethanolic extract, Enzymatic assays, Halocnemum stobilaceum, Repellency, Toxicity, Tribolium castaneum

\section{INTRODUCTION}

Grains and milling products constitute a major part of the daily of human and animal populations among. The most important risk associated with flour and

\footnotetext{
${ }^{1}$ Fatma Acheuk (corresponding author: fatma.acheuk@yahoo.fr), Manel Moukadem, Souhila Allili, Laboratory of Valorization and Conservation of Biological Resources”Valcore”, Department of Biology, Faculty of Sciences, University of Boumerdes, Boumerdes, 35000 ALGERIA; Wassima Lakhdari, Abderramene Dahliz, National Institute of Agronomic Research, Station of Sidi Mehdi, Touggourt, ALGERIA; Khemais Abdellaoui, Department of Biological Sciences and Plants Protection, High Institute of agriculture, Chott Mariem, Sousse University, TUNISIA Paper presented at the $8^{\text {th }}$ International Scientific Agricultural Symposium "AGROSYM 2017".

Notes: The authors declare that they have no conflicts of interest. Authorship Form signed online.
} 
cereal product consumption is insect contamination, which is an important quality control problem of concern milling industries (Taban et al., 2017). Currently, there are different kinds of preventive and curative control measures to get protection from this pest and chemical pesticides are one of them (Habib and Karim, 2015).These insecticides bring about such serious problems as contamination of the environment, lethal effects in non-targeted organisms which can lead to a failure of biological control programs and insect resistance. Toxic residues on stored grain for human consumption are other problems related to chemical pesticides (Rajendran and Sriranjini, 2008). However, with growing evidence that many conventional pesticides can adversely affect the environment and the human safety, requirement for safer means of pest management have become crucial (Rozman et al., 2007). One such alternative is the use of botanical insecticides (Baskar et al., 2009).

In the co-evolution of plant-insect interactions, plants have been able to synthesize a wide range of products to defend themselves against insect attacks, including primary metabolites (e.g. proteinase, amylase inhibitor and lectins) and secondary metabolites (e.g. alkaloids, tannins and rotenoids) (Zanini-Martins et al., 2012). Indeed, plants may provide potential option to currently used insectcontrol agents because they constitute a rich source of bioactive chemicals. Plant secondary compounds have been, than, the subject of investigation for the past 20 years in an effort to discover new sources of botanical insecticides, repellents and antifeedants (Akhtar and Isman, 2004).The main advantage of phytochemical insecticides is that they could be prepared easily by farmers, small-scal industries and are potentially less expensive (Nikkon et al., 2009).

In Algeria, research on the discovery and exploitation of natural resources for the development of botanical insecticides, for pest control, has been undertaken for several years (Acheuk et al., 2012 ; 2017 a \& b; Acheuk and Doumandji-Mitiche, 2013 ; Dane, 2016).

Halophytes are an important group of plants and play key roles in the ecosystem. While they have been used by local communities for millennia, their full potential is still untapped. Some halophytes are now being harvested commercially to obtain gums, oils and resins for production of household goods, food processing, and heavy industrial applications. Other halophytes are well known for their bioactive derivatives and are essential ingredients for pharmaceuticals, agricultural pesticides, traditional medicines and natural cosmetics (Al-Oudat and Qadir, 2011).

Halocnemum strobilaceum is a halophilic Chenopodiaceae plant of saline and marshy areas, it's grows in damp salt soil (salinity $>90 \mathrm{dS} / \mathrm{m}$ ). The plant was grazed by sheep and camels, but Bedouins believe that overfeeding on this plant causes lung disease in camels (Al-Oudat and Qadir, 2011).

Currently, no data concerning the biological or the insecticidal effects of this plant is available. In the order to find alternative bioactive compounds to control Tirbolium castaneum, the present study has screened the repellency and the efficacy of the crude ethanolic extract of $H$. strobilaceum as potential 
botanical insecticide against this pest under laboratory conditions. Te effect of this extract on the detoxification enzyme Glutathione S-transferase (GST) and the neuroenzyme Acethylcolinesterase (AChE) was also investigated.

\section{MATERIAL AND METHODS \\ Plant collection and preparation of crude ethanolic extract}

The plant $H$. strobilaceumwas collected from Sidi Mehdi, Touggourt region (Southeastern part of Algeria) during autumn season in 2015. The plant was taxonomical identified and confirmed by Dr Benhouhou from the National High College of Agriculture, Algiers, Algeria. Aerial parts of $H$. strobilaceum were air dried in the shade and grounded into fine powder using electrical blender. The powder was stored at room temperature in hermetically sealed plastic boxes until extraction.

\section{Insect rearing}

Initial stock culture of $T$. castaneum was obtained from entomology laboratory of National Institute of Plant Protection, El-Harrach, Algiers. Beetles were reared, at zoology laboratory of Boumerdes University, in glass containers $(0.5 \mathrm{~L})$ containing wheat flour mixed with brewer's yeast $(10: 1 ; \mathrm{w} / \mathrm{w})$. The culture was maintained in the dark in growth incubators at $28-30^{\circ} \mathrm{C}$ and $70-80 \%$ $\mathrm{RH}$. Adults of 1-5 days post emergence were used in experiments.

\section{Preparation of crude ethanolic extract and phytochemical screening}

The crude ethanolic extract of the aerials parts of $H$. strobilaceum was prepared by macerating the powder for 3 days in ethanol, followed by filtration and evaporation at $40^{\circ} \mathrm{C}$. The dried extract was kept at $4{ }^{\circ} \mathrm{C}$ until further use. The ethanolic extract was tested for plant secondary metabolites, alkaloids, phenolic compounds, flavonoids, saponins, tannins, iridois and coumarins. Phytochemical screening of the extract was carried out according to the standard method of Dohou et al. (2003). Visible color change or precipitate formation was taken into consideration for presence (+) or absence (-) of particular active constituents.

\section{Repellent activity}

To assess the repellency activity of $H$. strobilaceum crude ethanolic extract against T. castaneum adults, an area preference method of McDonald et al. (1970), with sligh modifications, was adopted. The test was carried out under the same conditions described above for the mass rearing using glass Petri dishes as containers. Filter paper (Whatman $\mathrm{N}^{\circ} 1,9 \mathrm{~mm}$ ) was cut in half.

The test extract was tested at the concentration of $1000 \mu \mathrm{g}$. Test compounds were dissolved on acetone and $500 \mu \mathrm{l}$ of the test solution were applied uniformly to half filter paper disc. Another half was treated with acetone only.

Treated and untreated halves were air dried, carefully fixed and placed in Petri dishes. For each test twenty adults insects (1-5 days post emergence) were introduced at the centre for the Petri dishes. The number of insects on the two halves disks were recorded after 2 and $4 \mathrm{~h}$ from the beginning of the test. The percentage of repellency was calculated as follows: 
$\mathrm{PR}(\%)=(\mathrm{Nc}-\mathrm{Nt}) /(\mathrm{Nc}+\mathrm{Nt}) \times 100$

Nc: Number of insects on control part

$\mathrm{Nt}$ : Number of insects on treated part

The average values were then categorized according to the following scale:

$\begin{array}{ll}\text { Class } & \text { Repellency } \\ 0 & >0.01 \text { to } 0.1 \\ \text { I } & 0.1 \text { to } 20 \\ \text { II } & 20.1 \text { to } 40 \\ \text { III } & 40.1 \text { to } 60 \\ \text { IV } & 60.1 \text { to } 80 \\ \text { V } & 80.1 \text { to } 100\end{array}$

\section{Contact toxicity test}

The bioassay was carried out using five concentrations of the crude ethanolic extract: 100, 200, 400, 800 and $1000 \mu \mathrm{g}$ /insect. Test solutions were prepared using acetone as solvent. Unsexed adults insects were immobilized 15 min before the beginning of the test. Aliquots of $5 \mu \mathrm{L}$ of each tested concentration were topically applied onto the thorax of insects using micropipette applicator. For each concentration twenty insects were used in 5 replicates. Acetone was used for the control test. After treatment, insects were transferred into glass Petri dishes containing a mixture of wheat flour and brewer's yeast given as food. All treated and control insects were kept under the same conditions as described for the insect rearing. Insect's mortality was recorded daily and $\mathrm{LD}_{50}$ was calculated.

\section{Acetylcholinesterase and Gluthatione S-transferase assays}

The AChE activity was carried out following the method of Ellman et al. (1961) using acetylthiocholine as a substrate. Adults of $T$. castaneum were sampled from control and treated groups (1000 $\mu \mathrm{g} / \mathrm{insect})$. Pools of twenty adults were homogenized in the solution containing $38.03 \mathrm{mg}$ of ethylene glycol tetraacetic (EGTA), 1mL Triton X-100, $5.845 \mathrm{~g} \mathrm{NaCl}$ and $80 \mathrm{~mL}$ Tris buffer (10Mm, pH 7). The homogenate was centrifuged (5000 g for $5 \mathrm{~min}$ at $4^{\circ} \mathrm{C}$ ), and the resulting supernatant was used for enzymatic assay. The AChE activity was measured in aliquots $(100 \mu \mathrm{L})$ of resulting supernatants added to $100 \mu \mathrm{L}$ of 5-5' dithiobis-(2-nitrobenzoic acid) (DNTB) in Tris buffer (0.01 M, pH 8) and $1 \mathrm{~mL}$ Tris $(0.1 \mathrm{M}, \mathrm{pH}$ 8). After $5 \mathrm{~min}, 100 \mu \mathrm{L}$ of acetylthiocholine was added. Measurements were conducted at a wavelength of $412 \mathrm{~nm}$ with a run time of 20 minutes.

GST activities were determined with the soluble fraction as enzyme source. GST activities toward 1-chloro-2, 4-dinitrobenzene (CDNB) were measured according to Habig et al. (1974). Treated (1000 $\mu \mathrm{g} / \mathrm{insect})$ and control insect were homogenized in sodium phosphate buffer $(0.1 \mathrm{M}, \mathrm{pH} 6)$ and centrifuged (14000 g, $30 \mathrm{~min})$. Two hundred microliter of the resulting supernatant was added to $1.2 \mathrm{~mL}$ of reaction mixture containing $1 \mathrm{Mm}$ of CDNB 
and $5 \mathrm{Mm}$ of reduced glutathione (GST) in the homogenization buffer. Changes in absorbance were recorded at $340 \mathrm{~nm}$. Total protein content was determined according to method of Bradford (1976) using bovine serum albumin as a standard. Enzyme activities were expressed as $\mathrm{nMmin}^{-1} \mathrm{mg}^{-1}$ proteins. The percentage of activation or inhibition was calculated for each enzyme.

\section{Statistical analysis}

Results are expressed as means \pm standard deviation (SD). To identify significant effects of the treatments on the variables measured, data were submitted to a monofactorial ANOVA using XLSTAT 7.5.2. Means were compared using Tukey's HSD test $(\mathrm{P}<0.05)$.

\section{RESULTS AND DISCUSSION \\ Phytochemical screening}

The crude ethanolic extract of $H$. strobilaceumwas subjected to qualitative phytochemical screening to identify presence or absence of selected chemical constituents using classical methods of analysis. From phytochemical screening (Table1) we observed that the studied plant contains different groups of secondary products. The plant is rich in flavonoids, tannins, alkaloids, coumarins, antocyans and saponins. The study also shows that this plant does not contain iridoids.

Table 1.Qualitative phytochemical screening of crude ethanolicH. strobilaceum.

\begin{tabular}{|c|c|c|c|c|c|c|}
\hline Alkaloids & Antocyans & Comarins & Tannins & Saponins & Iridoids & Flavonoids \\
\hline+ & +++ & ++ & ++ & +++ & - & +++ \\
\hline
\end{tabular}

(-): Absent ; (+): Low presence ; (++): Moderate presence ; (+++): Strong presence

\section{Contact toxicity}

The tested extract exhibited obvious toxicity against adults of $T$. castaneum (Fig. 1). Indeed, the five tested doses caused mortalities of 15, 33.3, 41.6, 48.3 and 70\%, respectively, after 6 hours of exposure. The highest dose $\left(1000 \mu \mathrm{g} /\right.$ insect) generated 100 deaths after $96 \mathrm{~h}$ of exposure. The $\mathrm{LD}_{50}$ calculated $24 \mathrm{~h}$ after treatment was $225.4 \mu \mathrm{g} /$ insect.

\section{Repellent effect}

The extract tested at dose of $1000 \mu \mathrm{g} /$ insecte has a good repellent effect on adults of $T$. castaneum (Table 2). Repellent action varied depending on the time exposure. Indeed, the repulsively rate calculated after two hours of exposure was $60 \%$. After $4 \mathrm{~h}$ of exposure, the PR value was $89.26 \pm 5.2 \%$.

Table 2.Repellent activity of the crude ethanolic extract of the plant $H$. strobilaceum against adults of T. castaneum at differents exposure times.

\begin{tabular}{|l|c|c|}
\hline Exposure time & $2 \mathrm{~h}$ & $4 \mathrm{~h}$ \\
\hline$\%$ of repellency & $60 \pm 02^{\mathrm{b}}$ & $89.26 \pm 5.2^{\mathrm{a}}$ \\
\hline Class & III & $\mathrm{V}$ \\
\hline
\end{tabular}




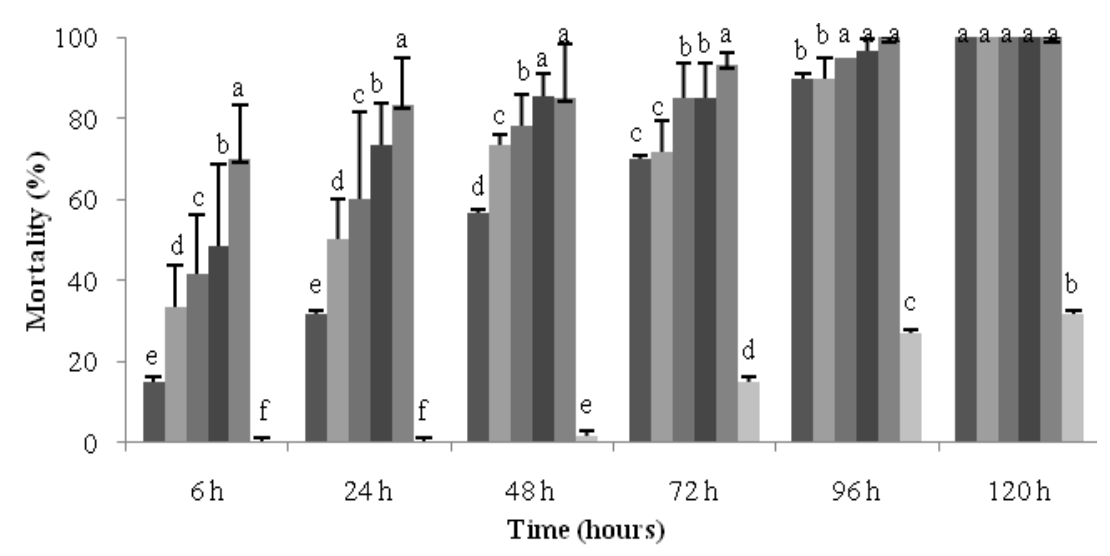

-D1: $100 \mu g=\mathrm{D} 2: 200 \mu \mathrm{g}=\mathrm{D} 3: 400 \mu \mathrm{g}=\mathrm{D} 4: 800 \mu \mathrm{g}=\mathrm{D} 5: 1000 \mu \mathrm{g}=\mathrm{Control}$

Figure 1. Toxicity of the crude ethanolic extract of $H$. strobilaceum applied topically to the adults of $T$. castaneum (Mean $\pm \mathrm{SD}$ ). $\mathrm{N}=20$ insects/replicate. Values followed by the same letter are not significantly different at $\mathrm{P}<$ 0.05 according to Tukey's test.

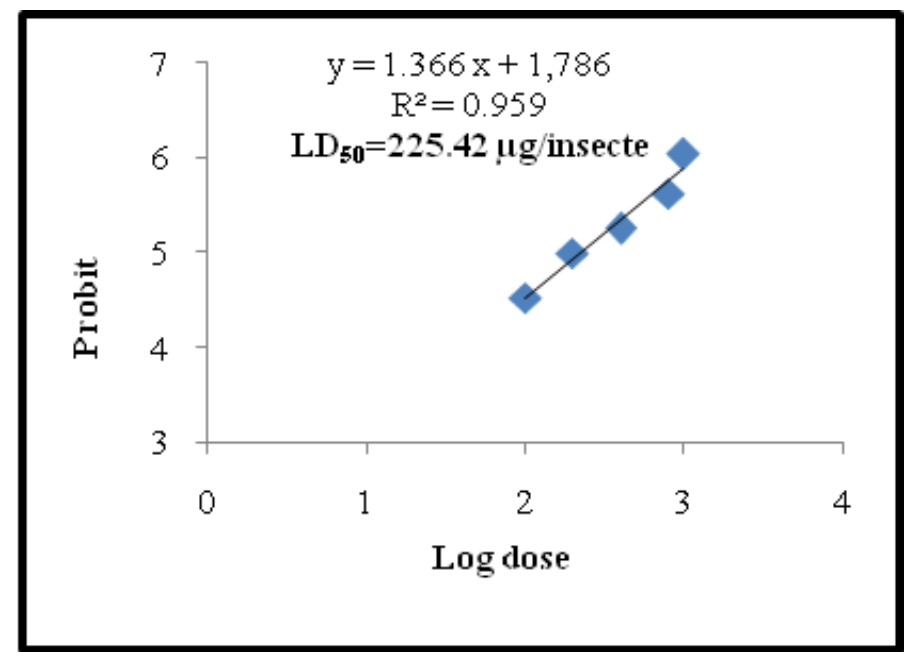

Figure 2. Effect of crude ethanolic extract of $H$. strobilaceum applied topically on the adults of the red flour beetle T.castaneum noted after $6 \mathrm{~h}$ of exposure (Mean $\pm \mathrm{SD}$ ). $\mathrm{N}=20$ insects/replicate.

\section{Enzymatic assays}

For enzymatic activities (Figs. 3 and 4), the results showed that the crude ethanolic extract of $H$. strobilaceum, applied at the dose of $1000 \mu \mathrm{g} / \mathrm{insect}$ inhibited significantly the AChE activity.

However, the extract has no significant effect on the GST activity. Indeed, the values of the enzyme activity are comparable between the control and treated series. 


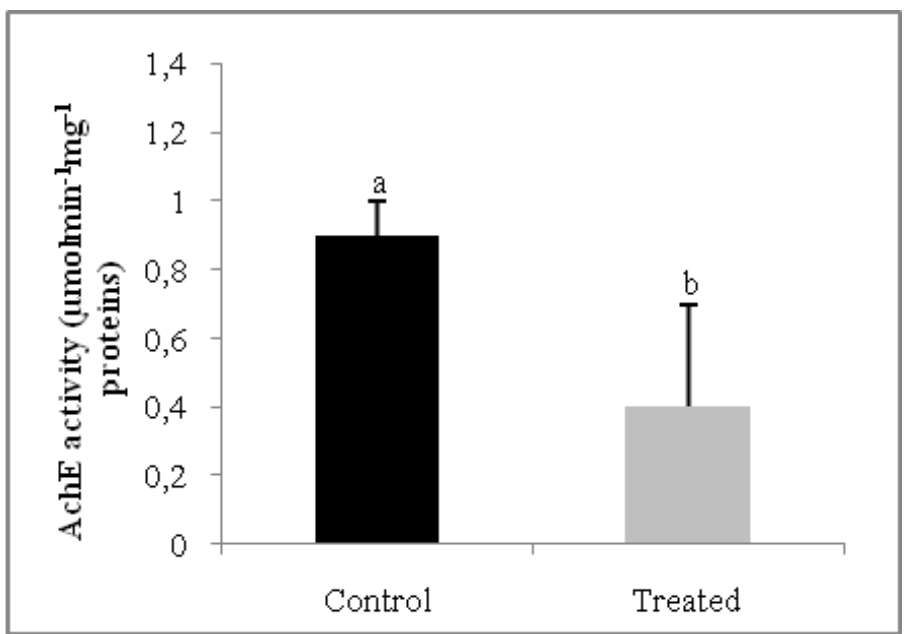

Figure 3. Effect of crude ethanolic extract of $H$. strobilaceumon AChE activity of the adults of the red flour beetle $T$. castaneum (Maen $\pm \mathrm{SD}$ ), $\mathrm{N}=20$ insects.

Different letters denote significant differences (Tukey's test, $\mathrm{p}<0.05$ ).

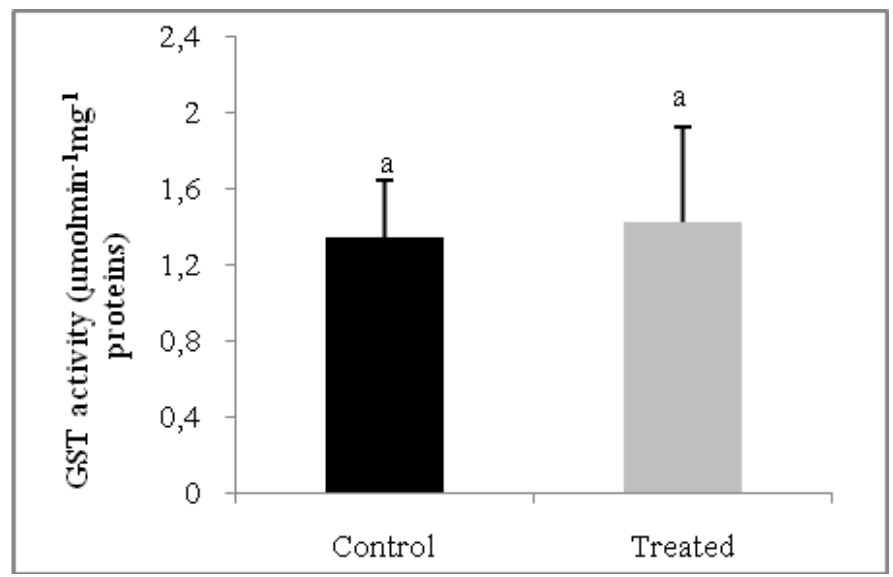

Figure 4. Effect of crude ethanolic extract of $H$. strobilaceumon GST activity of the adults of the red flour beetle $T$. castaneum (Maen $\pm \mathrm{SD}$ ), $\mathrm{N}=20$ insects.

Different letters denote significant differences (Tukey's test, $\mathrm{p}<0.05$ ).

Plant secondary compounds are an important biochemical basis for the plant defense against herbivores insects. Those compounds such as phenolics, alkaloids and proteins amino-acids are deleterious to insects and other herbivores by divers ways. Thus, they play a key role in plant defensive response to pests through acute toxicity and enzyme inhibition (Zhang et al. 2013). Phytochemical study of the studied plant showed the presence of various groups of natural products. The plant is rich in flavonoids, tannins, alkaloids and coumarins. The study also shows that this plant does not contain iridoids. The phytochemistry of this halophyte remains very poorly known, only two studies indicate the isolation 
of bio-actives compounds from this plant. Four coumarins: coumarin, hydroxy-3methylcoumarin, oreoselone, and heraclenin where isolated from the aerial part of H. strobilaceum (Miftakhova et al. 2001). Also, a new n-alkyl ester of 3,4dihydroxycinnamic acid (caffeic acid) has been isolated from this plant by Gibbons et al. (1999). Aerial plant parts contain 6.9\% protein, $2.15 \%$ fat, $17 \%$ fiber and $40.1 \%$ ash (El Shaer et al. 1991).

On insecticidal level, positive results for contact and repellent activity of the tested extract were obtained against the adults of the red flour beetles. Indeed, it was very clear that the percentage of mortality was directly proportional to the concentration of the test extract. Mortality increased from higher to lower concentration. The five tested doses caused mortalities of 15, 33.3, 41.6, 48.3 and $70 \%$, respectively, after 6 hours of exposure. The highest dose (1000 $\mu \mathrm{g} /$ insect) generated 100 deaths after $96 \mathrm{~h}$ of exposure. The $\mathrm{LD}_{50}$ calculated $24 \mathrm{~h}$ after treatment was $225.4 \mu \mathrm{g} /$ insect. The insecticidal properties of the crude extract of this plant could be rationalized by synergistic action of its all compounds, major compounds and some other minor compounds. Many plant extracts and essential oils have been reported to be effective against pests in stored products. The study conducted by Zardi-Bergaoui et al. (2008) indicate that the ethyl acetate crude extract and eight fractions $\mathrm{A}_{3}, \mathrm{~A}_{4}, \mathrm{P}_{8}, \mathrm{P}_{10}, \mathrm{~F}_{2}, \mathrm{~F}_{3}$ and $\mathrm{F}_{7}$ of Anacyclus cyrtolepidoides showed a significant inhibitory effect of $T$. confusum growth. 100 $\%$ mortality of adults was achieved 12 days after treatment using fractions $\mathrm{A}_{4}, \mathrm{P}_{8}$ and $F_{7}$. In a recent study of Phankaen et al. (2017), a significant mortality was recorded on fumigation assay with the dichloromethane extract of Coffea arabica. However, the active ingredient isolated of this extract did not induce similar toxicity as the dichloromethane extract. Results obtained by Saidana et al. (2010) indicated that the methanolic extract of tunisian halophyte Tamarix boveana caused significant and early mortalities and growth inhibition of the insect Trogoderma granarium at the concentration of of $50 \mu \mathrm{g} /$ disc.

In the present study, the plant extract showed potent repellent effect on $T$. castaneum adults. The PR value was $89.26 \pm 5.2 \%$ after $4 \mathrm{~h}$ of exposure at the testing concentration (1000 $\mu \mathrm{g} / \mathrm{insect})$. Many researchers have reported on the repellency of essential oils and plant extracts against insects, especially those infesting stored products. Essentials oils extracted from Stureja spp were strongly repellent against $T$. castaneum adults at the concentration of $1 \%(\mathrm{v} / \mathrm{v})$ after 4 hours of exposure (Taban et al., 2017). Phankaen et al. (2017) obtained a very strong repellency with the active compounds isolated from C. Arabica against $T$. castaneum adults.

Plant secondary compounds such as phenolics, alkaloids and non-protein amino acids are deleterious to insects and other herbivores in diverse ways. Thus, they play a key role in plant defensive response to pests through acute toxicity and enzyme inhibition (Zhanget al., 2013). The understanding of the mechanism of action of the extract of our plant on certain target enzymes remains important for a possible formulation of a bio-insecticide. The measurement of the activity of the GST and the AChE was carried out in this perspective. For enzymatic 
activities, data showed that the crude ethanolic extract of $H$. strobilaceum, at the dose of $1000 \mu \mathrm{g} / \mathrm{insect}$, has no significant effect on the GST activity. However, the extract inhibited the AChE activity. Our results were in agreement with those of Mami-Maazoun et al. (2017) wich showed that Urginea maritima bulbs extract was able to interfere with Sitophylus oryzae acetylcholinesterase enzyme andexhibited significant inhibitory effect on acetylcholinesterase activity. This inhibition could possibly be due to its high content in phenolic compounds and alkaloids. Once they penetrated inside the insect body, alkaloids and phenolic compounds reached nervous system and inhibited activity of acetylcholinesterase.

\section{CONCLUSION}

Based on the present study, it can be concluded that the crude ethanolic extract of the Saharian halophyte plant $H$. strobilaceum tested for its repellent activity and contact toxicity, exhibited obvious effects against the red flour beetle T. castaneum. For its acethylcolinesterase inhibition, this extract can be used as an insecticide against the pests of stored products. However, further tests are needed to develop a formulation of this natural insecticide.

\section{REFERENCES}

Acheuk F., Cusson M., Doumandji-Mitiche B. (2012). Effects of a methanolic extract of the plant Haplophyllum tuberculatum and of teflubenzuron on female reproduction in the migratory locust, Locusta migratoria (Orthoptera: Oedipodinae). Journal of Insect Physiology, 58, 335-341.

Acheuk F., Doumandji-Mitiche B. (2013). Insecticidal activity of alkaloids extract of Pergulariatomentosa (Asclepiadaceae) against fifth instar larvae of Locustamigratoriacinerascens (Fabricius 1781)(Orthoptera: Acrididae). International Journal of Science and Advanced Technology, 3(6), 8-13.

Acheuk, Lakhdari W., Abdellaoui K., Belaid M., Allouane R., Halouane F. (2017a). Phytochemical study and bioinsecticidal effect of the crude ethonolic extract of the algerian plant Artemisia judaica L. (asteraceae) against the black bean aphid, Aphis fabaeScop. Agriculture \& Forestry, 63 (1), 95-104.

Acheuk F., Belaid M., Lakhdari W., Abdellaoui K., Dehliz A., Mokrane K. (2017b). Repellency and toxicity of the crude ethanolic extract of Limoniastrumguyonianum against Triboliumcastaneum. Tunisian Journal of Plant Protection, 12, 71-81

Akhtar, Y., Isman, M.B., 2004. Comparative growth inhibitory and antifeedant effects

of plant extracts and pure allelochemicals on four phytophagous insect species. Journal of Applied Entomology, 128, 32-38.

Al-Oudat, M., Qadir, M. (2011).The halophytic flora of Syria.International Center for Agricultural Research in the Dry Areas, Aleppo, Syria.Viii, 186 pp.

Baskar K, Kingsley S, VendanSE, Paulraj MG, Duraipandiyan V. Ignacimuthu S. (2009). Antifeedant, larvicidal and pupicidal activities of Atalantiamonophylla (L) Correa against HelicoverpaarmigeraHubner (Lepidoptera: Noctuidae). Chemosphere, 75, 355-359.

Bradford M.M. (1976).A rapid and sensitive method for the quantitation of microgram quantities of protein utilizing the principle of protein-dye binding. Analytical Biochemistry,72, 248-254. 
Dane Y., Mouhouche F., Canela-Garayoa R., Delpino-Rius A. (2016). Phytochemical Analysis of Methanolic Extracts of Artemisia absinthium L. 1753 (Asteraceae), Juniperus phoenicea L., and Tetraclinis articulata (Vahl) Mast, 1892 (Cupressaceae) and evaluation of their biological activity for stored grain protection. Arabian Journal for Science and Engineering, 41(6), 2147-2158.

Dohou W., Yamni K., Tahrouch S., Idrissi Hassani L.M., Bado A. Guira N. (2003). Screening phytochimiques d'une endemique ibére-macrowave, Thymelaea lythroides. Bulletin de la Société de Pharmacie de Bordeaux, 142, 61-78.

Ellman G.L., Courtney K.D., Andres V., Featherstone A. (1961). A new and rapid colorimetric determination of acetylcholinesterase activity. Biochemical Pharmacology, 7, 88-95.

El-Shaer, H.M., Kandil, H.M., Khamis, H.S. (1991). Salt marsh plants ensiled with dried broiler litters as a feed stuff for sheep and goats. Journal of Agricultural Science, Mansoura University, 16,1524-1534.

Gibbons S., Mathew K.T., Gra A.I., (1999). A caffeic acid ester from Halocnemumstrobilaceum.Phytochemistry, 51, 465-467.

Habib M.R., Karim M.R., (2016). haracterization and insecticidal activity of CalotropisgiganteaL. flower extract against Triboliumcastaneum (Herbst). Asian Pacific Journal of Tropical Disease, 6(12), 996-999.

Habig W.H., Pabst M.J., Jakoby W.B., (1974). Glutathione S-transferases, the first enzymatic step in mercapturic acid.Journal of Biological Chemistry, 249, 71307139.

Mami-Maazoun A., Ben-Hlel T.A, Haouel-Hamdi S., BelhadjF ., Mediouni-Ben Jemâa D., Nejib-Marzouki M., (2017). Screening for insecticidal potential and acetylcholinesterase activity inhibition of Urgineamaritima bulbs extract for the control of Sitophilus oryzae (L.). Journal of Asia-Pacific Entomology, 20, 752760 .

McDonald, L.L., Guyn R.H., Speirs, R.D., (1970). Preliminary evaluation of new candidate materials as toxicants, repellents and attractants against stored-product insects.Agricultural Research Service, US Department of Agriculture, Washington, Marketing Research Report N. 882.

Miftakhova, A.F., Burasheva, G.S., Abilov, Z.A., Ahmad, V.U., Zahid, M. (2001).Coumarins from aerial part of Halocnemumstrobilaceum.Fitoterapia, 72(3), 319-321.

Nikkon, F., Habib, M.R., Karim, M.R., Ferdousi, Z., Rahman, M.M., Haque, M.E., (2009).Insecticidal activity of flower of Tageteserecta L. against Triboliumcastaneum (Herbst).Research Journal of Agriculture and Biological Sciences, 5, 748-753.

Phankaen Y., Manaprasertsak A., Pluempanupat W., Koul O., Kainoh Y., Bullangpoti V., (2017).Toxicity and repellent action of Coffeaarabica against Triboliumcastaneum (Herbst) adults under laboratory conditions. Journal of Stored Products Research, 71, 112-118.

Rajendran S., SriranjiniV. (2008). Plant products as fumigants for stored-product insect control. Journal of Stored Products Research, 44, 126-135.

Rozman V., Kalinovica I., Korunicb Z. (2007). Toxicity of naturally occurring compounds of Lamiaceae and Lauraceae to three stored-product insects. Journal of Stored Products Research, 43, 349-355.

Saidana D., Ben Halima-Kamel M., Boussaada O., Mighri Z., Helal A.N. (2010).Potential bioinsecticide activities of some Tunisian halophytic species against Trogodermagranarium. Tunisian Journal of Plant Protection, 5, 51-62. 
Taban T., Saharkhiz M.J., Hooshmandi M. (2017). Insecticidal and repellent activity of three Satureja species against adult red flour beetles, Triboliumcastaneum (Coleoptera: Tenebrionidae). Acta EcologicaSinica, 37, 201-206.

Zanini Martins C.H, Machado Freire M.G., Postali Parra J.R., Rodrigues Macedo M.L., (2012). Physiological and biochemical effects of an aqueous extract of Koelreuteriapaniculata(Laxm.) seeds on Anticarsiagemmatalis (Huebner) (Lepidoptera: Noctuidae). SOAJ of Entomological Studies, 1, 81-93.

Zardi-Bergaoui A., Hammami S., Kamel Ben Halima M., Sakka-Rouis L. Boussaada O., Haouas D., Mighri Z., (2008). Insecticidal activities of Flowerheads of AnacycluscyrtolepidioidesPomelGrowing in Tunisia against Triboliumconfusum du Val. Journal of Entomology, 5 4, 277-283.

Zhang M., Fang T., Pu G., Sun X., Zhou X., Cai Q. (2013). Xenobiotic metabolism of plant secondary compounds in the English grain aphid, Sitobionavenae (F.) (Hemiptera: Aphididae). Pesticide Biochemistry and Physiology 107, 44-49.. 